\title{
Implementation of Anti-Corruption Education through PENETRASI (Penanaman Sembilan Nilai Karakter Anti Korupsi) Method for the Urban Village Community of Jabungan
}

Dina Wahyu Pritaningtias ${ }^{1}$, Anindhita Sekaring Barendriyas ${ }^{2}$, Amira Rahma Sabela ${ }^{3}$, Indah Sri Utari ${ }^{4}$ 1,2,3,4Faculty of Law, Universitas Negeri Semarang, Indonesia *Corresponding Author: D. W. Pritaningtias, email: dinawahyu863@gmail.com

Abstract: The importance of anti-corruption education for communities in the area of Jabunganan Village in particular among teenagers, because they were the agents of change for nation building Indonesia in order to form a generation that has integrity. Attempts are made to college student real work relating to the State University of Semarang 2019 in instilling the value of anti-corruption through the PENETRASI method (Penanaman Sembilan Nilai Karakter Anti Korupsi) by holding discussion, dissemination, training and games. In these efforts, contains multiple values, including the anti-corruption character: 1) Honest, 2) Fair, 3) Hardwork, 4) Caring, 5) Simple, 6) Daring, 7) Liability, 8) Independent, 9) Disciplines. These efforts include: Anti Corruption Week (Antik), Rumah Sampah (Ramah), Ruang Inspirasi (Rapi), dan Anti Suap (Asiap), Bank Sampah (Basah), Pelatihan Neraca Laba Rugi bagi UMKM, Lomba Pidato Tema Anti Korupsi (Ladang Tikus), Pelatihan Pembuatan Briket dari Sampah Organik, Psikodrama, Mitigasi Bencana, Infografis Anti Korupsi, Permainan Ular Tangga dan Festival Anak Sholeh.

Keywords: anti-corruption education; nine values of anti-corruption character

\section{How to cite:}

Pritaningtias, D.W., Barendriyas, A.S., Sabela, A.R., \& Utari, I.S. 'Implementation of Anti-Corruption Education through PENETRASI (Penanaman Sembilan Nilai Karakter Anti Korupsi) Method for the Urban Village Community of Jabungan.' Indonesian Journal of Advocacy and Legal Services, 1(1), 45-64. DOI: 10.15294/ijals.v1i1.33752 


\section{A. Introduction}

Anti-corruption education is an education program on corruption that aims to build and increase citizens, ${ }^{1}$ especially concerning to the awareness of the dangers and consequences of acts of corruption. Anti-Corruption Education has a role in the lives of people who have a stake in corruption prevention because basically they are agents of national change in the history of the nation of Indonesia. Basically, the Government of Indonesia through the Corruption Eradication Commission (KPK) based on Law Number 30 of 2002 concerning the Corruption Eradication Commission, the Corruption Eradication Commission (KPK) was given the mandate to eradicate corruption professionally, intensively, and continuously. KPK is an independent state institution, which in carrying out its duties and authorities is free from any power. KPK has the task of coordinating with agencies authorized to eradicate corruption; supervision of agencies authorized to eradicate corruption; carry out investigations, investigations and prosecutions of corrupt acts; take steps to prevent corruption; and monitor the implementation of state government. ${ }^{2}$ Although the Government of Indonesia has endeavored to eradicate corruption in Indonesia mandated by the KPK, corruption continues to flourish from small corruption to corruption that harms the country. Therefore, the role of the community is very important and needed in combating non-criminal corruption.

Anti-Corruption Education that we did in this Real Work Lecture activity raised a title, namely "Anti-Corruption Education for Jabungan Village Residents in Efforts to Provide Education About Corruption through the PENETRATION Method (Planting Nine Anti-Corruption Character Values)", of which nine anti-corruption character values These consist of: 1) Honest, 2) Caring, 3) Independent, 4) Fair, 5) Hard Work, 6) Responsibility, 7) Courageous, 8) Simple, 9) Discipline. This Real Work Lecture Group seeks simple learning about anything that includes criminal acts of corruption and how to prevent them through these methods because the community here is still too ignorant about understanding what is a criminal act of corruption.

Planting the first nine values of anti-corruption character that is Honest which means the attitude of knowing, saying and doing what is

Maria Montessori, "Pendidikan Antikorupsi Sebagai Pendidikan Karakter di Sekolah”, Jurnal Demokrasi Vol. 11 No. 1 2012, p. 294

2 M. Ishaq Dwi Putra, Apa Saja Tugas dan Wewenang KPK?, http://indonesiabaik.id/motion_grafis/apa-saja-tugas-dan-wewenang-kpk, accessed on 24 August 2019 10:30 WIB 
right, can be trusted and not cheating. The second is Caring which means the attitude and action of paying attention and ignoring others. Third, Mandiri is the ability to solve, search for, and find solutions to one's own problems and not depend on others. The fourth is Adil, which means not taking sides and discriminating between certain groups or classes. Fifth, that is Hard Work, which means there is a sense of sincerity in completing a task or job. The sixth is Responsibility which means someone's attitude and behavior in carrying out the task. Seventh, that is Brave which means there is confidence in facing threats or difficulties. Eighth, namely Simple, which means to use something to taste. And the last is Discipline which means habits that are consistent with all forms of rules and regulations. ${ }^{3}$

The purpose of education is through the inculcation of anticorruption character values in the Jabungan Village because the people here especially teenagers have a low level of awareness about corruption. Therefore, because they are agents of change (agents of change) who will participate in realizing the future of Indonesia that is free from corruption, we as students who have already gained knowledge about anti-corruption education provide knowledge about education on anti-corruption values to the Jabunganan community. Join especially to teenagers.

In instilling anti-corruption education there needs to be several efforts. What are the efforts made to provide knowledge related to anticorruption to the Jabungan Village community, especially teenagers?

\section{B. Method}

Corruption for Jabungan Village Residents in Efforts to Provide Education about Corruption through the PENETRASI (Penanaman Sembilan Nilai Karakter Anti Korupsi) 'Embedding 9 Anti Corruption Character Values' ", consisted of various series of activities, namely socialization, discussion space, training, and games. In supporting the series of activities there are 13 work programs, each of which contains anti-corruption character values. The work program consists of Disaster Mitigation, PENETERASI PENETRASI (Penanaman Sembilan Nilai Karakter Anti Korupsi) through Psychodrama Method, Anti-Bribery, Anti Corruption Week, Anti-Corruption Theme Speech Competition, "Snake and Ladder" Sportsmanship Games, Inspiration Room, Anti-Corruption Infographic, Training on Making Briquettes from Organic Trash, Garbage Banks, Houses Trash, Income

\footnotetext{
3 Pusat Edukasi Antikorupsi, Nilai-Nilai Antikorupsi, https://aclc.kpk.go.id/materi/sikap-antikorupsi/infografis/nilai-nilai-antikorupsi, accssed on 22 August 2019 20:34 WIB
} 
Balance Training for MSMEs, and the Sholeh Children's Festival. The entire work program is carried out in Jabungan Village with the target of all levels of society, starting from children, adolescents, to adults. Through the aforementioned program it is hoped that all Jabungan residents can fight corruption by understanding and implementing 9 values of anti-corruption character in their daily lives.

Based on activities that have been carried out to the layers of society such as children and adults, understanding of corruption is very lacking. Not only that, their concern for the dangers of corruption has not been neatly fostered. Good survival is the comfort of their lives, when they feel their lives are sufficient then feel safe and do not care about the conditions around. Seeing the problem, our group provides an anti-corruption education to the community. After a number of stages, there is a change in mindset as we expect. The community begins to realize how important it is to care about the environment when someone does small acts of corruption. The thing we give to the public is to provide an understanding of the 9 values of anti-corruption character as the key to fighting corruption.

The word corruption comes from the Latin word Corruptio which means damage, depravity and decay. Corruption is often said to be an extraordinary crime, one of the reasons is because the extraordinary impact can cause damage both in scope, personal, family, community and wider life. The damage does not only occur in a short period of time, but can have a long term impact Corruption is caused by two factors, namely internal factors and external factors. Internal factors are the cause of corruption from individual factors, while external factors come from the environment or system.

In Law Number 31 of 1999 jo. Law Number 20 Year 2001 regarding Eradication of Corruption, in Chapter II Article 2 states that corruption is: "anyone who unlawfully commits acts of enriching oneself or another person or a corporation that can harm the State finances or the State's economy". The potential to commit acts of corruption, the perpetrators of corruption do not recognize gender or age and the conduct of corruption is always done with planning, none of the acts of corruption are carried out suddenly like other criminal crimes, because corruption is different from other criminal acts. The forms of criminal corruption include:

1) Harm the country's finances

2) Bribes

3) Extortion

4) Darkening in position

5) Conflict of interest

6) Gratuities 
7) Money laundering

Corruption prevention efforts can basically be done to reduce and eliminate the factors that cause corruption. Anti-corruption is an effort to prevent corruption by various efforts to increase individual awareness so as not to commit acts of corruption, as well as an effort to improve moral human resources. ${ }^{4}$ Unwittingly, many daily acts constitute a form of cadre of criminal acts of corruption, ranging from minor corruption to corruption that harms the country. This problem continues to increase so that it becomes a threat to the survival of the people of Indonesia, because corruption is a serious problem that we must eradicate through good habits by referring to 9 values of anti-corruption character. These values are:

1) Honest

The word honest in the Big Indonesian Dictionary (KBBI) means: righteous heart; not lying (stating as it is, not cheating, following the rules, sincere and sincere. Honesty is a basic value that is the main foundation for upholding one's integrity. Without honesty, it is difficult if someone can become a person of integrity. Someone is required to be able to speak honestly and not lying both to oneself and others, honesty will carry over to work so as to protect yourself against the temptation to cheat. Honest is one of the most important traits for social life, without honesty it cannot be trusted in socially if we believe that behavior Corruption is the evolution of corrupt behavior over small things and is considered trivial, so this fact is one of the worrying proofs, setting an example and accustoming children from an early age to say everything that happens according to what they do or know.

Examples of honesty in children, children told by their parents to buy goods and given more money he must return the change back to his parents in accordance with the nominal return must not be less. Small habits that they do continuously will be able to form a strong character of children. The output of honesty that is owned will produce results of people who have personalities who always tell the truth and do not lie.

2) Care

Caring is a basic value and attitude to pay attention and act proactively towards the conditions or circumstances around us. Caring is an attitude of our partisanship to involve ourselves in the problems, circumstances or conditions that occur around us. Everyone certainly has an opinion that we must respect their existence Respect for the opinion of fellow family members is a form of caring attitude that we can do in the

Fira Mubayyina, "SEMAI: 9 Nilai Anti Korupsi Dalam Pendidikan Anak Usia Dini”, Al-Hikmah: Indonesian Journal of Early Childhood Islamic Education, Vol 1 (2), 2017 p. 225 
home environment. Caring is those who are called to do something in order to inspire, change, kindness to the surrounding environment. When he sees a certain situation, when he witnesses the condition of society he will be moved to do something. What is done is expected to improve or help the surrounding conditions.

Caring is an attitude to pay attention to human values, always moved to help other human difficulties. A caring attitude is an attitude to try to awaken the independence that exists in society. People who care are people who cannot stay silent, see weaknesses, stand by and let bad conditions continue to occur in society, so the most important obligation is to always put themselves in a position to defend their interests, fight for their rights their rights, become companions and friends for their lives and advocate and help small and oppressed communities.

3) Independent

Independent is able to stand on its own feet, meaning that it does not depend much on others in any way. Independence is considered as an important thing that must be owned by a leader, because without independence a person will not be able to lead others. Independent in the life of the community is necessary because independence is opening the way. Whereas those who prefer to depend on others will forever be in the shadow of that person.

\section{4) Discipline}

Discipline is obedience or obedience to regulations. Conversely, to regulate human life requires a disciplined life. The benefit of discipline is that a person can achieve his goals in a more efficient time. Discipline has the same impact as other anti-corruption values, which can foster the trust of others in various ways. Discipline can be realized among others in the form of the ability to manage time well, adherence to all applicable rules and regulations, do everything in a timely manner, and focus on work. Examples of discipline in work are coming to work on time, not late, because we are late entering work together, including corruption, in this case time corruption.

5) Hard work

Hard work in the Big Indonesian Dictionary means a serious effort to achieve goals that are carried out continuously, not easily giving up in facing problems or challenges. An example that can be given in everyday life is to give a gift for the results of the work done by children in getting good grades at school. This is done in order that, to achieve something requires hard work and to introduce to children not to achieve something in an instant way. So that later when the child wants to become a rich person must work hard to get money, not by taking money that does not belong to 
him. Hard work is based on a will within oneself. Hard work is important in order to achieve results that are in accordance with what is desired.

6) Responsibility

Responsibility is the state of being obliged to bear everything (if anything happens may be prosecuted, blamed and sued). Someone who has responsibilities will have a tendency to complete tasks better. Someone who can carry out even the smallest of responsibilities well will get the trust of others. The application of the value of responsibility can be realized in the form of study in earnest, graduating on time with good grades, doing academic tasks well, maintaining the mandate and trust given.

7) Fair

Fair is defined as the same behavior in everyone, treating people the way we want to be treated, impartial, balanced between rights and obligations. Examples of examples that can be adapted in a community environment are neighboring parents and socializing to all people not looking at their possessions, rich or poor. This can be imitated by children so that everyone is impartial and friends to see his background first.

8) Simple

Simple is an attitude or behavior not excessive to something and more concerned with the benefits and objectives. Show the attitude as it is, do not force yourself by making efforts that are prohibited by the norm to take that is not really his right, inviting children to be diligent in saving and using according to their needs, children who are accustomed to being modest will be realized will not take the opportunity to cheat, because one of the causes of someone committing acts of corruption is an opportunity other than their greedy intentions and nature.

9) Brave

Dare is a great sense of confidence in facing challenges, not afraid in facing something that is believed to be true. Examples of examples that can be given to children are parents who dare to remind others who make mistakes and break rules. It can be imitated by children to do courage if there is someone who does wrong that is found in the surrounding environment can be reminded when making mistakes not to make mistakes anymore. It is expected that courage behavior in children can be applied so that later adults when they encounter cheats that occur both in the environment his work or the environment outside his job he will have the courage to report also to the authorities. 


\section{Result and Discussion}

1. Implementation of PENETRASI (Penanaman Sembilan Nilai Karakter Anti Korupsi) in Jabungan Village

a. Anti Corruption Week (ANTIK)

Teach anti-corruption values can be Teaching anti-corruption values can be started by introducing the children about good or bad behavior, right and wrong behavior, behavior that is appropriate or not in accordance with norms, this will provide good teaching to children and can be used as a foundation for behavior. by the child. Anti-corruption education is a conscious and planned effort to realize a teaching and learning process that is critical of the national anti-corruption values. The learning objectives of anti-corruption education are: 1) when they enter the community, students have enough provision to be able to understand ethics at every level of the "social leaders" they live in, 2) comprehensively understand the importance of ethics in both the public and private sectors, 3) recognize and understand the adverse effects of corruption on public trust and competition in the international world, and 4) have the courage and wisdom to eradicate corruption. ${ }^{5}$ Thus anti-corruption education does not merely emphasize cognitive aspects or knowledge alone, but also emphasizes the formation of character (affective), and moral awareness in fighting corruption behavior. Anti-corruption education aims to create a generation of young people who have good moral and anti-corrupt behavior. ${ }^{6}$

The problem of corruption continues to increase, causing unrest for the community given the ongoing regeneration. Indonesian children as the golden generation of the nation have great potential to build the nation, create rapid progress, and realize the dream of the nation's predecessors to always advance Indonesia. In building a nation, a generation that is intelligent, independent and responsible for the tasks given is needed. This gives a warning to us that it is important to teach kindness to every Indonesian child. Provide broad knowledge, educate children to be a strong and independent generation, and teach anti-corruption behavior so as not to create harm to themselves, others, and the country.

5 Eko Handoyo, et.al., "Penanaman Nilai-Nilai Kejujuran Melalui Pendidikan Antikorupsi di SMA Negeri 6 Semarang”, Jurnal Abdimas Vol. 14 No. 2 (2010), hal. 2

6 Agus Wibowo, Pendidikan Karakter, Strategi Membangun Karakter Bangsa Berperadaban, Yogyakarta: Pustaka Pelajar, 2012, p. 28 


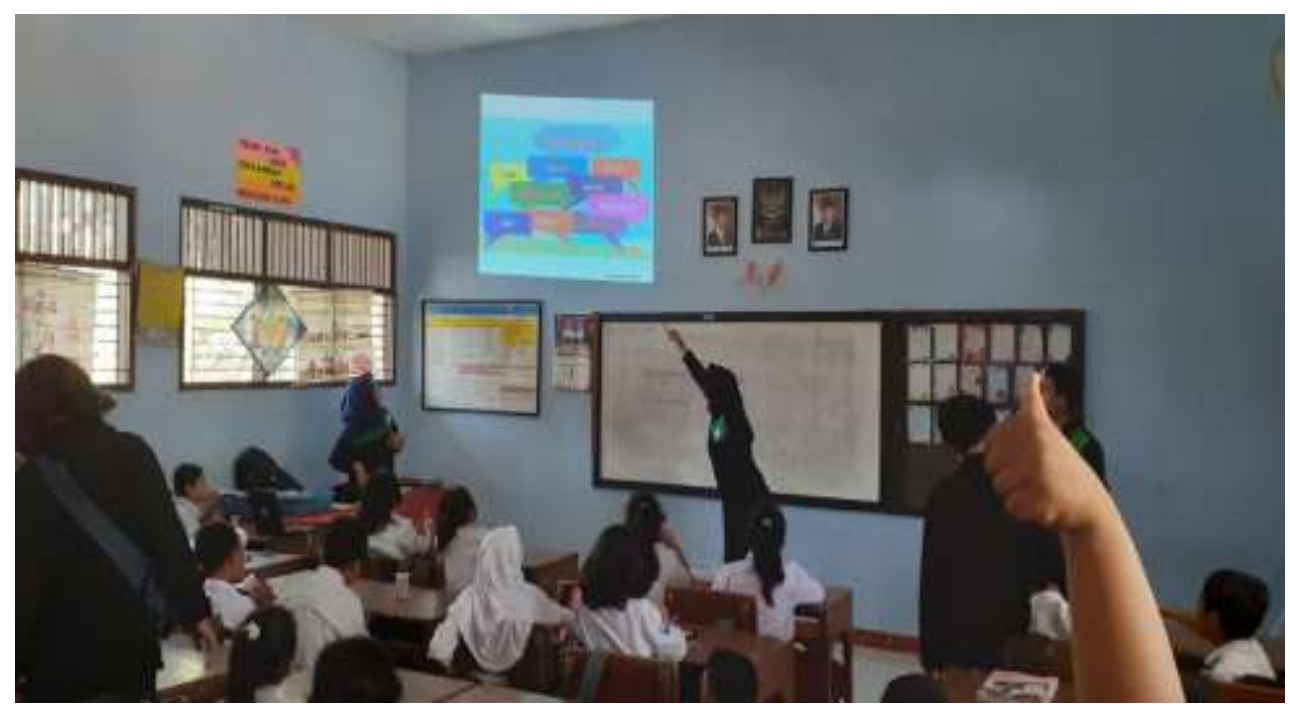

Figure 1. Anti-Corruption Week Socialization at SDN Jabunganan. Source: Personal Document, 2019

Providing knowledge about the 9 values of anti-corruption character is not only applied to adults. It is very important we give this knowledge to children, where they are the next generation of the nation. Different understanding from adults, makes us think more broadly how to provide knowledge to children. We made a one-week work program that we named Anti Corruption Week, in this program consisting of a series of activities which provided an understanding of the 9 values of anti-corruption character and then provided an implementation container for the value of honesty, the honesty canteen.

Anti Corruption Week is a program that forms honest and disciplined behavior and increases students' sense of responsibility so that they have an independent nature and anti-corruption culture. As well as student participation and enthusiasm in participating in this program. The absence of a forum for applying anti-corruption values in the school environment. Providing information on what forms of petty corruption are commonly carried out by students they may not even be aware of. Providing honesty canteen facilities to implement anti-corruption values, namely honesty values. Anti-corruption education must be meaningful learning by experiencing or experiential learning so it does not merely condition the students only to know, but also to be given the opportunity to make decisions and choices for themselves. ${ }^{7}$

Nuriani Laura Malau Gurning, "Implementasi Pendidikan Antikorupsi Melalui Warung Kejujuran di SMP Keluarga Kudus”, Jurnal Teknologi Pendidikan dan Pembelajaran Vol. 2 No. 1 (2014), p. 94 


\section{b. PENETRASI (Penanaman 9 Nilai Karakter Anti Korupsi) by PSIKODRAMA Method}

Corrupt behavior that is often found in elementary school children is cheating, lying, late coming to school, and yelling friends. However, corrupt behavior does not only originate from one's own behavior, it can also create corrupt behavior by listening to other people's stories that create a feeling of wanting to do the act so that it can be accepted in play groups. The story given becomes someone else's virus if in the future someone else experiences the same thing will choose to take the solution that he has heard and so on. ${ }^{8}$

Corruption eradication is not enough to overcome only by relying on law enforcement processes. Eliminating corruption also needs to be done with preventive measures, among others by instilling religious values, corruption-free morals or anti-corruption learning through various educational institutions. Educational institutions have a very strategic position in instilling an anti-corruption mentality. ${ }^{9}$ Instilling anti-corruption nature from an early age through primary, secondary and higher education institutions is expected to create students free of corruption. With the learning material provided is expected to save the golden generation so that it becomes a generation that is free of corruption. Elementary School is one of the educational institutions that used as a second home for children to gain knowledge, especially regarding anti-corruption. The simple corrupt behavior that we encounter in the elementary school environment is time corruption, when the entrance bell has rang sometimes there are still children who have not come to school. This behavior can be becomes a habit if not immediately acted upon. In this case education becomes a very important element for public awareness of the adverse effects of corruption. In the Indonesian context, combating corruption must use various instruments to be more effective. Through changes in values that are instilled since childhood, children will experience changes in mindset and are more sensitive to the problem of corruption. Changes in behavior since childhood are important considering the children will one day replace the older generation as well as the successor to the nation's leadership. ${ }^{10}$

One interesting learning method in providing knowledge about the value of anti-corruption through PENETERASI (Planting 9 Anti-Corruption

$8 \quad$ Lailatul Izza, "Menumbuhkan Nilai-Nilai Anti Korupsi pada Anak untuk Membentuk Karakter Melalui Semai Games di MDTA Rabithatul Ulum Pekanbaru", Phychopolytan: Jurnal Psikologi, Vol. 2 No.3, February 2019, p. 85

9 Ahmad Zuber, "Strategi Anti Korupsi Melalui Pendekatan Pendidikan Formal dan KPK (Komisi Pemberantasan Korupsi)", Journal of Development and Social Change, Vol. 1, No. 2, October 2018, p. 180

10 Agus Pramusinto, "Mencari Alternatif Strategi Pemberantasan Korupsi”, Jurnal Kebijakan dan Administrasi Publik, Vol. 13, No. 1, May 2009, p. 2 
Character Values) through PSIKODRAMA. We teach this method to Jabungan State Elementary School students in a series of Anti-Corruption Education Scientific Work (KKN) activities. The implementation of this program begins by providing an understanding of 9 anti-corruption values to 5th grade elementary school students, after which division of roles is performed and provides text drama to 5 students who have been selected to play the drama Planting 9 anti-corruption values.

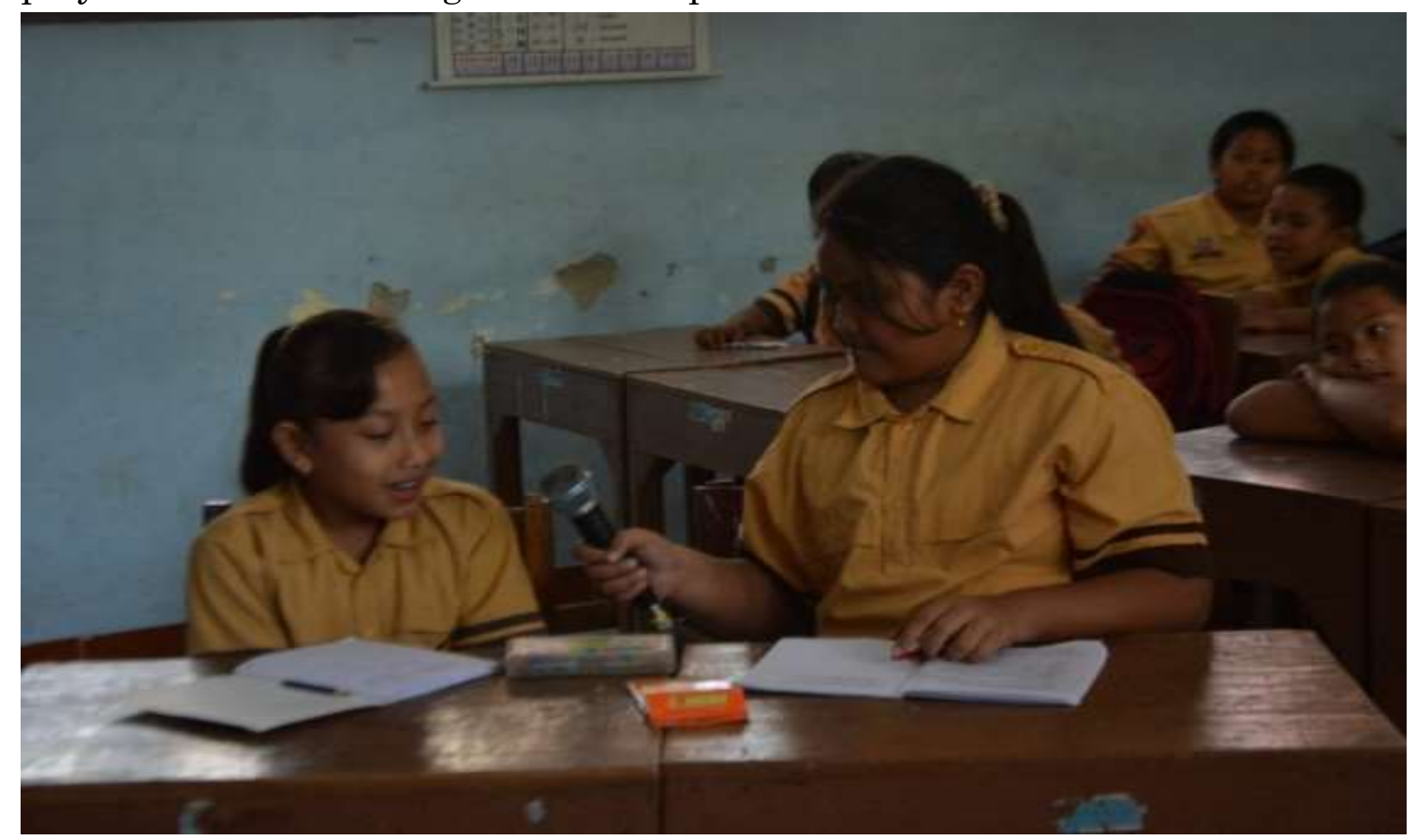

Figure 2. Psychodrama by fifth grade students of Jabungan State Elementary School. Source: Personal Document, 2019

Corey believes that psychodrama is a role play intended so that the individual can get a better understanding of himself, can find concepts in himself, state his needs, and express his reaction to pressures against him. With this psychodrama, it is hoped that school children can consciously understand themselves, understand the material of anti-corruption values and then apply it in their daily lives. ${ }^{11}$ Through the psychodrama technique provided, it is hoped that it will increase future optimism in students and think about a more positive individual's future. Psychodrama is a training technique developed by Jacob L. Moreno. ${ }^{12}$

Psychodrama is a group therapy approach, in which the client plays the roles and situations of past, present, or future life in an experiment to

11 Tatiek Romlah, "Teori dan Praktek Bimbingan Kelompok", Malang, Universitas Negeri Malang, 2006, p.107

12 JohanaE. Prawitasari, "Psikologi Klinis Pengantar Terapan Mikro dan Makro", Jakarta, Penerbit Erlangga, 2011, p. 182 
gain a deeper understanding so as to achieve emotion. Important events are played back to help clients connect with feelings that are not revealed and not realized, providing a channel for full disclosure of these feelings, leading to new behavior. ${ }^{13}$

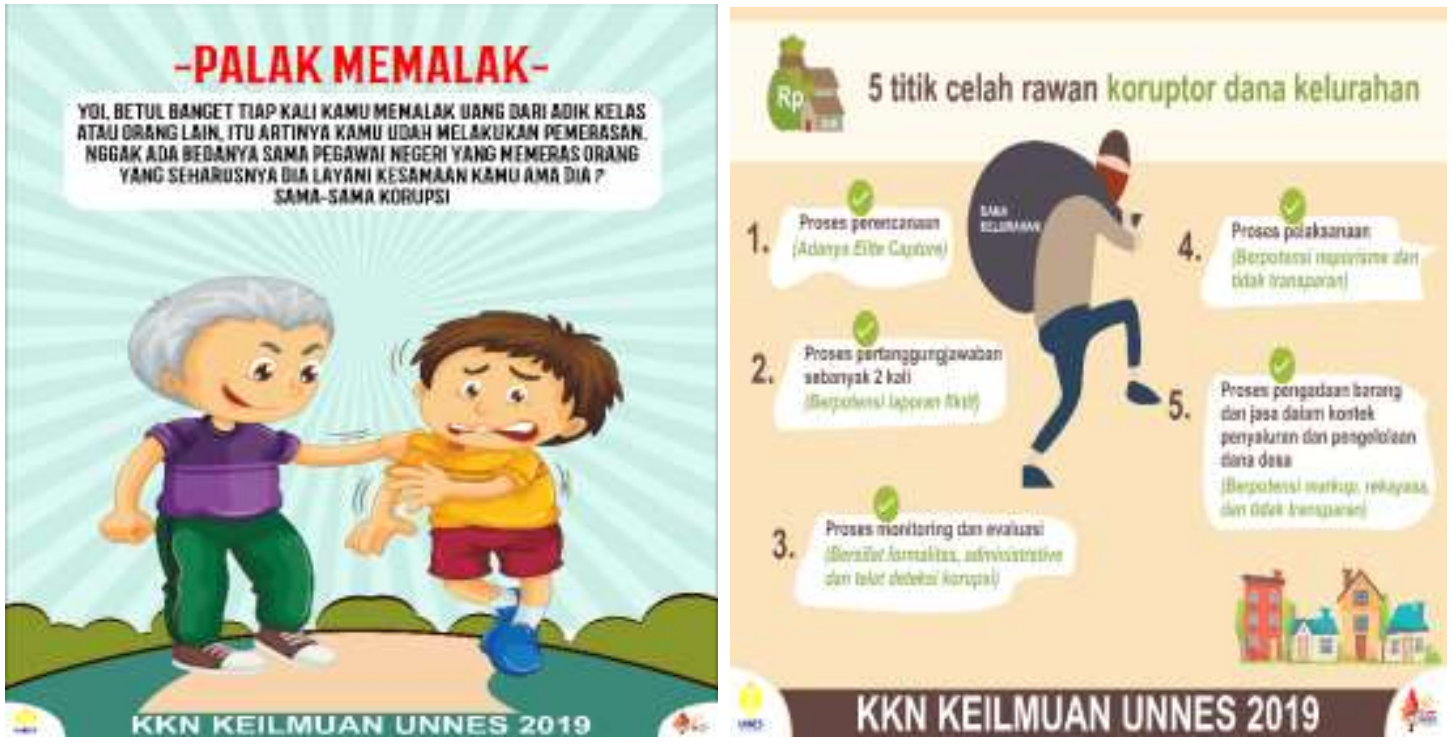

Figure 3. Infographics of Anti Corruption. Source: Personal Document, 2019

Psychodrama was chosen as the method of delivering 9 material anticorruption character values because through this method it is hoped that students can easily understand one by one the value of anti-corruption characters by playing a drama. Practice the nine values of anti-corruption character as if they experienced the incident and find solutions to each problem.

In the drama it is divided into two drama groups, the first being the value of independent, honest, and responsibility. In this drama it tells about friendship between Sila and Winda, Sila who accidentally breaks winda crayons honestly and is responsible for replacing the crayons by independently saving using her pocket money. The second drama is about the value of discipline, courage, hard work. In this second drama tells about Dini who is always disciplined to leave on time, dare to come forward to answer the questions Mr. teacher and work hard to do the questions given by the teacher. The results achieved in this program are students of grade 5 in elementary school becoming aware of the 9 values of anti-corruption characters that have been practiced in the drama and it is hoped that students can practice the 9 values of anti-corruption in daily life.

13 Ahmad Riyadi, et.al., "Effectiveness of Group Therapy: Psychodrama in Improving Positive Self-Concept Towards Captive Child", Prosiding Seminar Nasional Psikologi Indigenous UMP 2015, p. 22 


\section{c. Anti-Bribery, Anti Suap (ASIAP)}

Corruption is a phenomenon that is a culture, a person's behavior that has been built from the values they know and believe. They build these values through systematic socialization. Good habits are needed, starting from changing the mindset which then forms good habits and behavior so that later the behavior becomes a habit. It is very important to change the bad values found in social life.

The size of the corruption does not always indicate the size of the adverse effects caused. Small-scale corruption may have worse impacts than large-scale corruption. This is caused by the frequent practice of small-scale corruption directly related to marginalized communities. ${ }^{14}$ Anti-corruption education is actually very important to prevent the occurrence of acts of corruption. If the KPK and several other anti-corruption institutions catch corruptors, then the anti-corruption education is also important to prevent new corruptors, it seems like the importance of morals, ethics, morals, and so on. Likewise, anti-corruption education is important in preventing the occurrence of criminal acts of corruption. ${ }^{15}$

Seeing the increasing tendency of corruption, we can see the tendency of governance practices as a whole. Judging from the number of disclosures in the case, we can interpret the data as follows: first, corruption practices during the day of smekain are rife; second, there is seriousness in controlling corruption. Therefore, it is not surprising that people's assessment of practicegovernance (voice and accountability, government effectiveness, rule of law, political stability, regulatory quality, control of corruption) show positive ratings. 16

Listening to the causes of corruption, it can be concluded related to human aspects, regulations, bureaucracy, political will, commitment, and consistency of law enforcement and community culture. For this reason, the broad strategy adopted includes the following aspects: 17

1) Increasing the integrity and ethics of state administrators

2) Strengthening and accelerating bureaucratic reform

3) Strengthening the anti-corruption culture of the community

4) Firm, consistent and integrated law enforcement

Based on point $c$ above regarding strengthening of the anti-corruption culture of the community is one of the important things in efforts to

Agus Pramusinto, Op.Cit., p.3

Jamaluddin Rabain, "Perspektif Islam tentang Korupsi", Jurnal Pemikiran Islam, Vol. 39, No. 2, July-December 2014, p. 188

16 Agus Pramusinto, Op.Cit., p. 7

17 Bambang Waluyo, "Optimalisasi Pemberantasan Korupsi", Jurnal Yuridis, Vol. 1 No.2, December 2014, p. 175 
eradicate corruption. In this case the community's attitude towards corrupt practices is crucial in efforts to eradicate corruption. By making efforts to straighten the values of the community it is felt able to fortify them from corrupt behavior. This effort was carried out through counseling and antibribery campaigns. The existence of this campaign is expected to be able to shape the attitude and mental attitude of the society that is anti-corruption because the benefits derived from corruptive behavior are not worth the suffering that will be obtained later.Anti-bribery is a program in an effort to increase the understanding of residents and village officials

in Jabungan Sub-district, Banyumanik District, Semarang City regarding the category or type of bribery, who can bribe and who can be bribed, the threat of punishment in the event of bribery, and quick response to if knowing that bribery has taken place in his environment on a daily basis. The community, especially in Jabungan Village, does not yet know what bribery is and how the bribery category is in the community or in the village government environment. From various scope of society, most of them do not know about bribery. So from the need to be given knowledge about the categories of bribery which are included in corruption.

The activity is carried out with counseling and the "Bribery Identification" campaign begins by providing knowledge of what bribes are, categories or types of bribes, who can bribe and who can be bribed, the threat of punishment in the event of bribery, and quick response when they find out that bribery has occurred in its environment.

This activity aims to build a community that is aware of the importance of honest and disciplined behavior as an effort to create an anticorruption culture and good governance for the government at the village / Village level.

The results of activities in the provision of counseling and this campaign are citizens aware of the threat of bribery in the daily environment and if there is an indication of bribery then residents can immediately report to the KPK according to the mechanism we have explained at the time of counseling without fearing that their identities will be revealed. This is in line with the theme of Scientific Community Service which is true to provide knowledge and awareness in life by instilling anticorruption values.

\section{d. Disaster Mitigation, Mitigasi Bencana (SINCAN)}

Disaster is a situation that our arrival is not unexpected before, where in that condition there can be damage, death to humans or objects or houses and all the furniture that we have and does not rule out the possibility of animals and plants to die. While natural disasters are 
disasters caused by natural events, disasters can occur through a long process or a certain situation in a very fast time without any signs.

Disasters often cause public panic and cause prolonged suffering and sadness, such as: injury, death, economic pressure due to loss of business or work and property, loss of family members and damage to infrastructure and the environment. Natural disasters often occur in Indonesia. This requires knowledge and understanding of natural disasters that might occur in the future. Natural disasters also become the center of great attention in attracting and inviting responses from various parties towards disaster victims.

The disaster mitigation program was a direct speaker from the Semarang City BPBD, disseminating information to the community of Jabungan Village. Implemented by disseminating material on disaster, both natural disasters and social disasters, prepared to face disasters and teach responsive attitudes in dealing with disasters by applying methods of socialization and discussion. In this case the community is equipped with knowledge and understanding of disasters, to be able to deal with them when exposed to disasters and contribute to disaster management efforts themselves.

Because after all it is realized that disaster management does not only involve the government and other parties, but the role of the community in it is very important. Everyone has their own definition of the word natural disaster. The result achieved from disaster mitigation is to instill community understanding that each of them is an important component so that the Jabungan sub-district becomes a Tangguh subdistrict when natural and social disasters occur. After the next stage of disaster mitigation socialization, FPRB (Youth Disaster Volunteer Forum) was made up consisting of LPMK, BKM, PKK, Youth Organization, FKK, KSB, Linmas. 


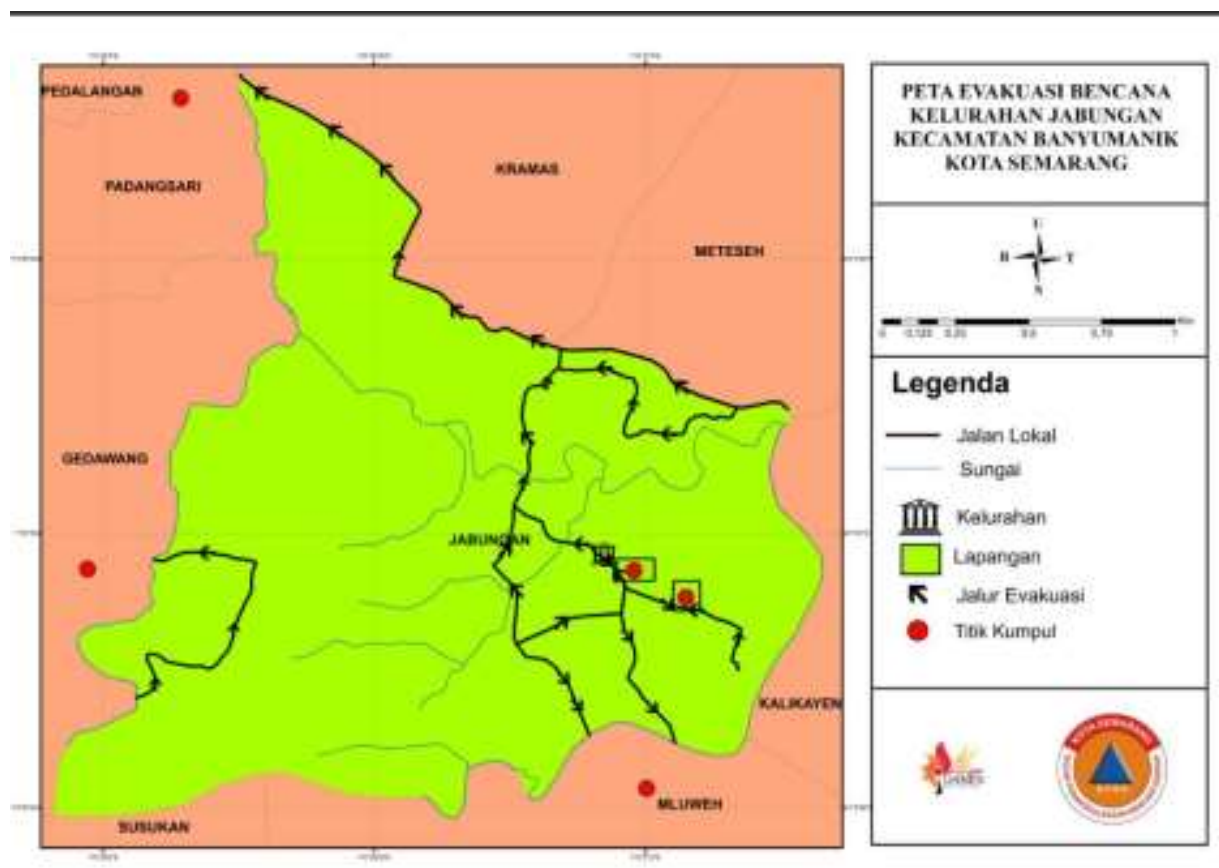

Figure 4. Outcome of the Combined Area Disaster Mitigation Program Disaster Mitigation. Source: Badan Penanggulangan Bencana Daerah Kota Semarang, 2019

\section{Conclusion}

Because there is not yet a forum for applying anti-corruption values in the school environment, we teach the Anti-Corruption Week teaching method to give students an idea of anti-corruption values to the Jabungan State Elementary School through planting knowledge of nine anti-corruption values through counseling any forms of petty corruption. which is usually done by students who may not themselves be aware of who then provide an implementation container of the value of honesty that is the honesty canteen.

As well as interesting learning in providing knowledge about the value of anti-corruption through PENETERASI (Penanaman 9 Nilai Karakter Anti Korupsi) through Psychodrama. Psychodrama is a group therapy approach, in which the client plays the roles and situations of past, present, or future life in an experiment to gain a deeper understanding so as to achieve emotion. Through the psychodrama technique provided, it is hoped that it will increase future optimism in students and think about a more positive individual's future.

Efforts to educate and campaign against bribery through the AntiBribery Socialization method. This activity is carried out with counseling 
and the "Bribery Identification" campaign begins by providing knowledge of what bribes, categories or types of bribes, who can do bribes and who can be bribed, the threat of punishment in the event of bribery, and quick response when knowing that bribery has occurred in the environment. . Anti-bribery is a program in an effort to improve the understanding of residents and village officials in Jabungan Village regarding the category or type of bribery, who can bribe and who can be bribed, the threat of punishment in the event of bribery, and quick to be responsive to know that bribery has occurred in their environment. day-to-day aim to build a community that is aware of the importance of honest and disciplined behavior as an effort to create an anti-corruption culture and good governance for the government at the village / Village level.

The disaster mitigation program was a direct speaker from the Semarang City BPBD, disseminating to the people of Jabungan Village the material on disaster, both natural disasters and social disasters, being prepared to face disasters and teaching responsive attitudes in dealing with disasters by applying socialization and discussion methods. In this case the community is equipped with knowledge and understanding of disasters, to be able to deal with them when exposed to disasters and contribute to disaster management efforts themselves. The result achieved from disaster mitigation is to instill community understanding that each of them is an important component so that the Jabungan Village becomes a Tangguh Disaster Village.

\section{Acknowledgments}

Prevention of criminal acts of corruption through Anti-Corruption Education using the PENETRATION method (Penanaman 9 Nilai Karakter Anti Korupsi) in Jabungan Sub-district is running in accordance with what we expect. The community, teenagers, and children who live in the Jabungan District are very enthusiastic about our work programs. Of course, with this, we students of Semarang State University 2019 Semarang State University of Science Study Work truly express their gratitude to: Jabungan Village Chief and Jabungan Village staff; Jabungan State Elementary School; MI Al Kaeriyah; Youth organization; TPQ Hidayatulaliyah; Semarang City Regional Disaster Management Agency (BPBD) and Youth KSB (Sigap Bencana Village) Jabungan Village; PKK cadre in Jabungan Village; MSME "Peek Chips"; Residents of RW 1-RW 6, Jabungan Village; KKN PPM-XIX Team at Semarang University. Those who have collaborated and provided us with the opportunity to carry out the work programs that have been prepared. We hope that our dedication in Jabungan Village will provide 
benefits and a large positive impact on the progress of this Village, especially in the willingness of citizens to practice the simple knowledge we have given during lectures. Real Work in Jabungan Sub-District, as well as being honest and open with each other about the loopholes to commit criminal acts of corruption.

\section{E. Declaration of Conflicting Interests}

The authors state that there is no potential conflict of interest in the research, authorship, and / or publication / publication of this article.

\section{F. Funding}

Program of the community services and research funded by Authors it self as well as publication. Authors declare that there is no sponsorhip or any other parties funded the program.

\section{G. References}

Gurning, N.L.M. (2014). Implementasi Pendidikan Antikorupsi Melalui Warung Kejujuran di SMP Keluarga Kudus. Jurnal Teknologi Pendidikan dan Pembelajaran, 2(1), 93-102.

Handoyo, E. et.al. (2010). Penanaman Nilai-Nilai Kejujuran Melalui Pendidikan Antikorupsi di SMA Negeri 6 Semarang. Jurnal Abdimas, 14(2), 1-7

Izza, L. (2019). Menumbuhkan Nilai-Nilai Anti Korupsi pada Anak untuk Membentuk Karakter Melalui Semai Games di MDTA Rabithatul Ulum Pekanbaru. Phychopolytan: Jurnal Psikologi, 2(3), 84-95.

Montessori, M. (2012). Pendidikan Antikorupsi Sebagai Pendidikan Karakter di Sekolah. Jurnal Demokrasi, 11(1), 293-301.

Mubayyina, F. (2017). SEMAI: 9 Nilai Anti Korupsi Dalam Pendidikan Anak Usia Dini. Al-Hikmah: Indonesian Journal of Early Childhood Islamic Education, 1(2), 223-238.

Pramusinto, A. (2019). Mencari Alternatif Strategi Pemberantasan Korupsi. Jurnal Kebijakan dan Administrasi Publik, 13(1), 1-7.

Prawitasari, J.E. (2011). Psikologi Klinis Pengantar Terapan Mikro dan Makro. Jakarta: Penerbit Erlangga. 
Pusat Edukasi Antikorupsi. (2019). Nilai-Nilai Antikorupsi. Accessed on 22 August 2019, retrieved from https://aclc.kpk.go.id/materi/sikapantikorupsi/infografis/nilai-nilai-antikorupsi

Putra, M.I.D. (2019). Apa Saja Tugas dan Wewenang KPK?. Accessed on 24 August 2019, retrieved from http://indonesiabaik.id/motion_grafis/apa-saja-tugas-dan-wewenang$\underline{\mathrm{kpk}}$

Rabain, J. (2014). Perspektif Islam tentang Korupsi. Jurnal Pemikiran Islam, 39(2), 187-198.

Riyadi, A. et.al., (2015). Effectiveness of Group Therapy: Psychodrama in Improving Positive Self-Concept towards Captive Child. Prosiding Seminar Nasional Psikologi Indigenous UMP.

Romlah, T. (2006). Teori dan Praktek Bimbingan Kelompok. Malang: Universitas Negeri Malang.

Waluyo, B. (2014). Optimalisasi Pemberantasan Korupsi. Jurnal Yuridis, $1(2), 169-182$.

Wibowo, A. (2012). Pendidikan Karakter, Strategi Membangun Karakter Bangsa Berperadaban. Yogyakarta: Pustaka Pelajar.

Zuber, A. (2018). Strategi Anti Korupsi Melalui Pendekatan Pendidikan Formal dan KPK (Komisi Pemberantasan Korupsi). Journal of Development and Social Change, 1(2), 178-190. 


\title{
QUOTE
}

\section{The best way to find your self is to lose yourself in the service of others}

\author{
Mahatma Gandhi
}

Copyrights (C) 2019 by Auhtor(s). This work is licensed under a Creative Commons Attribution-NonCommercial-ShareAlike 4.0 International License. All writings published in this journal are personal views of the authors and do not represent the views of this journal and the author's affiliated institutions. 